\title{
(Nie)zdolność do reformowania szkolnictwa wyższego i nauki w Polsce, czyli zaniedbania w zakresie wiedzy ${ }^{2}$
}

\begin{abstract}
The paper focuses of the role of scientific knowledge in the processes of conducting reforms and public policy. The case of higher education and science reforms in Poland - carried out over the period of 25 years of new political, social and economic conditions - shows primary knowledge negligence of the reformers which undoubtedly affected the nature of the current higher education and science system, reformed several times already. It also furnishes some recommendations on how these processes may be improved.

The theoretical background of the study is the sociological perspective based on the findings of sociology of knowledge which makes it possible to look at the problem in question in a more comprehensive manner than when other disciplines are applied, such as public policy science, administration science or public management - a sub-discipline of management science.
\end{abstract}

1 Agnieszka Dziedziczak-Foltyn, Instytut Socjologii, Wydział Ekonomiczno-Socjologiczny, Uniwersytet Łódzki, a.dziedziczak@uni.lodz.pl.

2 Sygnalizowane w niniejszym artykule wątki dotyczące zdolności do projektowania i prowadzenia polityki szkolnictwa wyższego i nauki, w tym reformowania tych sektorów, zostały szerzej opisane w kilku artykułach autorki, a przede wszystkim w rozprawie habilitacyjnej Reforma szkolnictwa wyższego w Polsce w debacie publicznej. Bilans dyskusji o uniwersytetach (1990-2015). Łódź: Wydawnictwo Uniwersytetu Łódzkiego (w druku). 
In the empirical dimension, the starting point was the concept of metaknowledge (i.e knowledge about knowledge), encompassing three aspects connected with generating and using knowledge in the context of higher education and science reforms, which are ring-fenced basing on different methodologies:

(1) knowledge about reforming - theoretical literature query;

(2) knowledge in reforming - analysis of experts' reports;

(3) knowledge of reformers - results of studies on the processes of learning and knowledge management in public administration.

The postulate of a broader use of scientific knowledge in reform processes is an attempt to indicate one of the key directions to follow when repairing the higher education and science system. For that reason, the role of social sciences has been highlighted, including, in particular, the role of sociologists in reform processes (as theoreticians and experts in the area of higher education and science). Furthermore, the need for sociologists to go back to the role of social experts-engineers has been signalled.

\section{Key words:}

higher education and science, reforming, sociology of knowledge, public policy

\section{WPROWADZENIE}

Tytułowa kwestia zdolności do reformowania (reform capacity), jako narzędzie polityk publicznych, rzadko bywa traktowana jako bezpośredni czynnik decydujący o powodzeniu reform szkolnictwa wyższego i nauki w Polsce. Jest ona zakładana implicite. Najczęściej uwaga badaczy i komentatorów koncentruje się na substancjalnym wymiarze reform - obejmującym planowane i wprowadzane przez ministerstwo zmiany w zakresie finansowania, zarządzania, modelu kariery akademickiej i kształcenia na poziomie wyższym. Znacznie mniej interesuje badaczy wymiar znawstwa i biegłości w reformowaniu oraz technologii bądź inżynierii społecznej ukierunkowanej na doskonalenie tych sektorów metodami naukowymi. Po części jest to efekt zniechęcenia do inżynierii społecznej w wydaniu władz PRL, a także braku pomysłu na zrehabilitowanie tego sposobu powiązania nauki z działaniem. Paradoksalnie dyskurs naukowy zdominowały pojęcia sugerujące dyktat wiedzy związany z koncepcjami rozwoju społeczeństwa opartego na wiedzy czy gospodarki napędzanej wiedzą (czy też raczej na kapitale intelektualnym). 
Tymczasem procesy reformowania szkolnictwa wyższego i nauki w Polsce na przestrzeni ćwierćwiecza funkcjonowania w zmienionych warunkach polityczno-społeczno-gospodarczych ujawniły szereg zaniedbań reformatorów w zakresie wytwarzania i wykorzystania wiedzy niezbędnej w procesach „urządzania” obu systemów, które niewątpliwie wpłynęły na ich obecny kształt i już przez ten fakt zasługują na naukową analizę czy choćby refleksję. Prześledzona pod tym kątem historia reformowania umożliwia sformułowanie wniosków i rekomendacji, które same w sobie stanowią zasób wiedzy przydatny w modernizowaniu systemów szkolnictwa wyższego i nauki. Trafnym dla ich całościowego ujęcia wydaje się pojęcie metawiedzy (wiedzy o wiedzy), które łączy wiedzę o istocie reformowania i wiedzę o przedmiocie reformowania (znawstwo) z umiejętnością ich wykorzystania w praktyce reformowania (biegłość) adekwatnie do potrzeb wszystkich interesariuszy, metod, miejsca i czasu.

Z tego powodu głównym celem empirycznym proponowanego w tekście studium zdolności do reformowania jest uwydatnienie roli wiedzy w procesach reformowania i polityce publicznej. Wynika stąd potrzeba interdyscyplinarnego ujęcia tego procesu obejmującego takie dyscypliny, jak: socjologia prawa czy socjologia polityki publicznej, nauki o polityce publicznej, nauki o administracji czy subdyscyplinę nauk o zarządzaniu - zarządzanie publiczne. Ramą teoretyczną spajającą proponowane eksploracje jest jednak perspektywa socjologiczna, która pozwala ująć omawianą problematykę bardziej wszechstronnie niż wymienione wyżej dyscypliny. Przyjęcie perspektywy socjologii wiedzy daje podwaliny teoretyczne dla zagadnień związanych z tworzeniem i wykorzystywaniem wiedzy na rzecz reform. Sięgnięcie do dorobku socjologii umożliwia ponadto ukazanie istotnej roli socjologów w nabywaniu znawstwa i kształtowaniu biegłości w reformowaniu - zarówno w wymiarze stricte naukowym, jak i pragmatycznym. Jednakże wiedza ekspercka poddana zostaje na łamach tego tekstu równolegle poznawczej afirmacji i krytyce. Socjologiczny wgląd w procesy generowania wiedzy specjalistycznej przydatnej do objaśniania i kształtowania świata społecznego ma bowiem za zadanie wskazać nie tylko na brak naukowego podejścia do reformowania, ale również zagrożenia utylitarnej optyki, co powinno wzmagać ostrożność wobec specjalistycznej wiedzy ekspertów będącej na usługach decydentów. 


\section{WIEDZA NAUKOWA W UJĘCIU SOCJOLOGII WIEDZY}

Przyjęcie socjologii wiedzy za punkt wyjścia dla poniższego studium wynika z faktu, iż zajmuje się ona wszelkimi postaciami wiedzy: od potocznej po naukową, aczkolwiek w tym konkretnym przypadku mowa jest o wiedzy naukowej w zakresie nauk społecznych, zwłaszcza socjologii (socjologii wiedzy naukowej). W przekonaniu Józefa Niżnika (1989, s. 198) socjologię wiedzy (w odniesieniu do nauk społecznych) charakteryzuje wyjątkowa zależność jej wymiaru epistemologicznego i praktycznego: „ważność epistemologiczna wiedzy społecznej jest konstytuowana w związku z praktyką społeczną, a równocześnie, aby ją wykazać, trzeba aspekt praktyczny wiedzy odróżnić od jej aspektu epistemologicznego”. Dalszy wywód, choć natury teoretycznej, ma zatem za zadanie ukazać przydatność tego rozróżnienia zarówno dla teorii, jak i praktyki reformowania.

\subsection{WIEDZA TEORETYCZNA I WIEDZA EKSPERCKA}

Według Floriana Znanieckiego (1984, s. 262-263), który ponad 70 lat temu pisał o socjologii wiedzy i technologii społecznej, refleksja nad faktami społecznymi może przybierać formę opisowo-wyjaśniającą (teoretyczną) lub formę wartościująco-normatywną (praktyczną). W ten sposób czyste poznanie rzeczywistości przeciwstawione jest ocenie tej rzeczywistości i jej podporządkowaniu czynnym dążnością ludzkim. Stąd już tylko krok do ogólnego podziału uczonych na mędrców i technologów, który to podział ucieleśnia najważniejsze sposoby uprawiania wiedzy przez ludzi nauki. Jednocześnie zakłada on, że mędrzec może pełnić funkcję społeczną technologa.

Z powyższym rozróżnieniem koresponduje propozycja podziału na dwie opozycyjne orientacje aksjonormatywne dotyczące roli uczonego dokonana przez Janusza Goćkowskiego (1978). Przeciwstawiając sobie dwa podstawowe pierwiastki nauki (episteme i techne) wyznaczające wartości, którym ludzie nauki podporządkowują swoje poszukiwania poznawcze, autor wyróżnił kategorię „klerków” i „ekspertów”. Toczy się jednak między nimi spór nie tylko o wyższość orientacji poznawczej, ale równocześnie orientacji społecznej, która różnicuje obie kategorie ze względu na etos uczonych. Nie bez znaczenia w kształtowaniu owego etosu jest kwestia kultury politycznej, a szczególnie polityki wobec nauki ze strony władz państwowych. Trzy dekady później J. Goćkowski (2009, s. 123-152) zaproponował inne nazewnictwo tych samych kategorii, wskazując „teoretyków” i „ekspertów”, oraz ich ujęcie deskryptywne w odniesieniu do przemian społecznych. Odróżniają ich od siebie typy postaw, działań i style uczestnictwa w przemianach oraz - mogący budzić pewne 
kontrowersje - typ relacji z decydentami. Otóż teoretyk nie musi być partnerem współczesnych mu decydentów, adresuje swoje utwory do innych teoretyków, a decydenci jedynie mogą skorzystać lub nie z jego prac teoretycznych. Ekspert jest zobligowany do dialogu i kooperacji ze współczesnymi mu decydentami w imię rozwiązywania problemów poznawczych typu praktycznego. Ważnym dla wywodu tego tekstu elementem owego portretu teoretyków i ekspertów jest jednak fakt pewnej zależności pomiędzy nimi. Teoretyk dostarcza ekspertowi fundament naukowy dla jego działalności w rolach konsultanta, diagnosty, projektanta. Ekspert dostarcza teoretykowi rozeznania w opcjach aksjologicznych i kompetencjach prakseologicznych decydentów jako wiedzy o komponentach obiektów studiów służących tworzeniu konstruktów teoretycznych. W ten sposób obie role mogą splatać się w jednej osobie eksperta, który jest zarówno specjalistą wykształconym w naukach teoretycznych (niezależnie od tego, czy jest prawnikiem, ekonomistą, socjologiem, politologiem, psychologiem itd.), jak i rozwiązującym problemy z zakresu stosowania nauk praktycznych (Goćkowski, Machowska, 2005, s. 54). Co ciekawe, misją socjologów jest występowanie w obu tych rolach, a dodatkowo w roli mediatora pomiędzy zwolennikami episteme i zwolennikami techne (Goćkowski, 1978, s. 80).

\subsection{NIEKTÓRE UWARUNKOWANIA WYKORZYSTANIA WIEDZY EKSPERCKIEJ PRZEZ DECYDENTÓW}

Rozbudowana charakterystyka obu sposobów - jakby powiedział Florian Znaniecki (1984, s. 537) - „uprawiania wiedzy naukowej” przez teoretyka i przez praktyka-eksperta dowodzi wyraźnie konieczności połączenia aktywności teoretyczno-eksperckiej na rzecz większej racjonalizacji procesów reformowania. Autor ten (1984, s. 269, 272) upatrywał w socjologii naukowej (przeciwstawianej „socjologii zdrowego rozsądku”, na której opierała się wcześniej technologia społeczna) główną podstawę wykształcenia wszelkiego rodzaju praktyków, przeznaczonych do wpływania na rzeczywistość społeczną. Co więcej, podkreślał on (1984, s. 141) użyteczność socjologii w gromadzeniu danych i wyciąganiu wniosków, których efekty przynoszą korzyści zarówno dla teorii socjologicznej, jak i działalności władz państwowych. Niemniej spożytkowanie naukowej socjologii i naukowej technologii społecznej przez decydentów zdaniem J. Goćkowskiego (2009, s. 121) utrudniają: (1) niedostateczna znajomość takiej wiedzy, (2) brak stałego systemu komunikowania się i współpracy teoretyków i praktyków (ekspertów), (3) brak ustalonych reguł i norm korzystania z usług ekspertów, (4) nieufność wobec specjalistów spoza kręgu partyjnego (czy szerzej - światopoglądowego), (5) obawa 
przed naukowym obiektywizmem i krytycyzmem jako czynnikami zagrażającymi autorytetowi decydentów korzystających z socjotechnik.

O ile aktywność teoretyków może pozostawać obojętna politykom-decydentom-reformatorom, o tyle aktywność ekspercka, rozumiana jako „doskonalenie skuteczności socjotechniki przez proponowanie rozwiązań pozytywnych i odradzanie działań przynoszących szkody i straty”, stanowi atrakcyjny dla rządzących aspekt wiedzy naukowej. W teorii istnieją jednak pewne reguły (,warunki brzegowe”) dla optymalnej współpracy decydentów z ekspertami. Po stronie decydenta leży dbałość o: (1) dobór eksperta spośród znawców odpowiadających decydentowi ideologicznie, (2) dobór eksperta pod względem jego kompetencji merytorycznych, (3) poinformowanie eksperta o zamierzeniach, by zminimalizować ryzyko niezgodności funkcji zamierzonej od funkcji rzeczywistej ekspertyzy, (4) wyznaczenie standardów i kryteriów funkcjonalności zamawianej ekspertyzy, (5) dostarczenie danych i materiałów przydatnych do ekspertyzy. Po stronie eksperta natomiast leży odpowiedzialność za: (1) aksjologiczne dopasowanie do oferty decydenta, (2) merytoryczne sprostanie ofercie decydenta, (3) ocenę szans na właściwe wykonanie ekspertyzy na podstawie danych i materiałów oferenta (Goćkowski, Machowska, 2005, s. 51). Przytoczone powyżej „warunki brzegowe” współpracy ekspertów z decydentami ukazują złożoność tej relacji, która nie opiera się wyłącznie na kryteriach merytorycznych. Usytuowanie w obrębie określonej ideologii i zaangażowanie określonych systemów aksjonormatywnych niesie z sobą inne jeszcze ryzyka niż te najbardziej oczywiste, jak niechęć decydentów do korzystania z wiedzy naukowej czy słabe kompetencje merytoryczne ekspertów.

\subsection{POTENCJALNE ZAGROŻENIA WYKORZYSTYWANIA WIEDZY EKSPERCKIEJ PRZEZ DECYDENTÓW}

Przykłady niefortunnej koalicji nauki z praktyką (a dokładnie polityką), dobitnie nazywane „zdradą klerków”, przytacza Marek Czyżewski (2012, s. 91-92). Autor zalicza do nich: (1) propagandową i agitacyjną służbę nauki na rzecz autorytarnych rządów, (2) biurokratyzację nauki obsługującej w imię dominującej ideologii biurokratyczny aparat państwa, (3) poddanie się płynnemu syndromowi „społeczeństwa wiedzy”. Przy czym dwa ostatnie przykłady dotyczą czasów współczesnych i mogą występować łącznie. Krytyka nadmiernej uległości nauki wobec praktyki wydaje się współcześnie coraz bardziej konieczna także ze względu na dwa inne aspekty „doradztwa naukowego”: niepełną profesjonalizację tego rodzaju pracy naukowej („uprawiania wiedzy naukowej”- przyp. autorki) oraz niewłaściwe 
interpretowanie czy naginanie faktów naukowych według kryteriów odpowiadających administracji publicznej i politykom (Ravetz, 2002, s. 44, 46).

\section{METAWIEDZA JAKO DEFICYTOWY ZASÓB REFORMATORÓW}

Ponad ćwierć wieku funkcjonowania systemów szkolnictwa wyższego i nauki w warunkach państwa demokratycznego i gospodarki wolnorynkowej pozwala na prześledzenie procesów związanych z generowaniem i wykorzystaniem wiedzy niezbędnej w projektowaniu polityki i będących jej konsekwencją reform obu systemów. Analiza tych procesów sięgająca nawet dalej wstecz, tj. do czasów reform podejmowanych przez władze PRL, dowodzi, że zarówno w tamtym okresie, jak i w trakcie transformacji ustrojowej była dostępna pewna wiedza socjologiczna dotycząca skutecznego reformowania. Można ją było, po koniecznej adaptacji do zmieniających się warunków politycznych, gospodarczych i społecznych, z pożytkiem wykorzystać, jednak bardzo długo tego nie uczyniono. Ów brak oparcia się w reformowaniu na osiągalnej, skądinąd, wiedzy stanowi jedno z zasadniczych zaniedbań w zakresie polityki szkolnictwa wyższego (polityki w praktyce nieobecnej do czasu ustawy Prawo o szkolnictwie wyższym z 2005 r. i słabo dostrzegalnej jeszcze kilka lat później).

Wskazanie w artykule wspomnianych zaniedbań wiązało się z zastosowaniem odmiennego doboru źródeł, stanowiących zarówno przekazy wiedzy naukowej, jak i wiedzy eksperckiej, co już per se ilustruje potrzebę aliansu pomiędzy teorią a praktyką w generowaniu nowej wiedzy. Zdaniem - piszącego o wiedzy społecznej z perspektywy zarządzania publicznego - Jerzego Hausnera (2012, s. 14) opanować świata społecznego nie można wyłącznie intelektualnie czy wyłącznie praktycznie. Konieczne jest łączenie perspektyw na zasadzie tworzenia teorii i wyprowadzania z nich praktycznych zaleceń z pespektywy uczestnika-obserwatora. Bowiem wiedza i teorie społeczne służą nie tylko opisywaniu i przewidywaniu rzeczywistości społecznej, lecz również jej współtworzeniu i zmienianiu. Jak zauważa Jerzy Wilkin (2012, s. 22, 24), prócz funkcji poznawczej (teoretycznej), która zastosowana do rozwiązywania konkretnych problemów społecznych staje się funkcją aplikacyjną (praktyczną), nauki społeczne pełnią dodatkowo funkcję ideologiczną (światopoglądową). Stąd rolą nauk społecznych - łączących wszystkie trzy funkcje - jest zdaniem tego autora dostarczanie zaplecza naukowo-eksperckiego dla polityk publicznych, coraz bardziej niezbędnych w rozwoju społeczno-gospodarczym kraju. W podobnym duchu (choć w innych warunkach ustrojowych) pisano o funkcjach i roli socjologów (Goćkowski, Łoś, Mikułowski- 
-Pomorski, 1981), wyróżniając trzy orientacje i typy socjologa: scjentystyczną (twórca teorii i diagnoz naukowych), socjotechniczną (ekspert i reformator), ideologiczną (wychowawca, przekaziciel określonej ideologii).

Przyjęta w tekście perspektywa socjologiczna pozwala na swego rodzaju fragmentację metawiedzy (wiedzy o wiedzy) związanej z reformowaniem uwzględniającą omawianą wielofunkcyjność nauk społecznych, w tym socjologii. Na jej potrzeby wyszczególnione zostały trzy kategorie wiedzy istotne dla polityki szkolnictwa wyższego i nauki, a przede wszystkim sztuki reformowania na poziomie systemowym: wiedza o reformowaniu (z przewagą wiedzy teoretycznej), wiedza w reformowaniu (z przewagą wiedzy eksperckiej) oraz wiedza reformatorów (wiedza manifestująca wiodącą ideologię rządzących, ale też odnosząca się do praktyki społecznej) $)^{3}$.

\subsection{WIEDZA O REFORMOWANIU}

Na podstawie kwerendy rodzimej literatury teoretycznej sformułować można wniosek o znikomej liczbie publikacji dostarczających bezpośrednią wiedzę o tym, w jaki sposób reformować (w sensie wiedzy habitualnej czy proceduralnej/operacyjnej), w przeciwieństwie do tego, co i jak reformować (w sensie wiedzy opisowej/deklaratywnej). Jeśli przyjąć, że reformowanie sprowadza się do procesu stanowienia prawa, pewne wskazówki na temat sztuki projektowania i wdrażania prawa dają socjologia prawa i prawoznawstwo. Z kolei z perspektywy formułowania polityk publicznych pojawiają się odniesienia do wiedzy o politykach. Reformy stanowią przedmiot badań socjologów, zwykle jednak w kontekście przedmiotu zjawisk podlegających reformowaniu i skuteczności wprowadzanych zmian, nie zaś skuteczności reformowania jako sui generis kwestii z zakresu wiedzy o reformowaniu.

W socjologii za znawcę procesu reformowania szkolnictwa wyższego uznać można Jana Szczepańskiego (1995, s. 22), który uprawiając socjologię empiryczną, pełnił różnorakie funkcje: doradzał politykom, pisał analityczne raporty, projektował reformy, występował w parlamencie, przewodniczył komitetom i ostrzegał, przede wszystkim jednak był uczonym, badaczem tworzącym naukę w zakresie badań szkolnictwa wyższego i oświaty. Socjolog ten na łamach swojego opracowania

3 Artykuł nie dotyczy reformowania na poziomie instytucji, w ramach którego bardziej uzasadniona byłaby analiza z zakresu socjologii organizacji czy teorii organizacji wykorzystująca koncepcję zarządzania wiedzą i organizacji uczącej się jako elementu budowania innowacyjności i konkurencyjności uczelni (Boguski, 2013) czy też bezpośrednio paradygmatu zarządzania uczelnią mówiącego o uniwersytecie opartym na wiedzy lub podporządkowanym wiedzy (Leja, 2013). 
Reformy, rewolucje, transformacje (1999, s. 20-21), jako jeden z dwóch czynników powodzenia reform - obok stopnia zorganizowania reformowanego systemu instytucji - wskazywał wiedzę o reformowanej rzeczywistości oraz wiedzę dotyczącą samych reform. Ów drugi zasób wiedzy obejmować miał zarówno wiedzę o tym, do kogo reforma jest adresowana, z jakim spotka się przyjęciem, jakie grupy (i jak silne) będą ją popierać a jakie będą się jej sprzeciwiać, jak i specjalistyczną wiedzę o działaniu reformatora, którą powinna posiadać cała grupa zaangażowana w proces reformowania. W związku z nią autor podkreślał znaczenie racjonalności metod reformowania i jakości kadry przygotowującej działania reformatorskie (1999, s. 32-33). Co ciekawe, nazywając reformy „działaniami technicznymi”, wymagającymi „socjotechniki”, J. Szczepański (1999, s. 23, 29) zastanawiał się też nad tym, „czy jakość reform nie jest także czynnikiem określającym reformy?”. Choć nie wybrzmiewa to jasno z jego tekstu, kwestie tego typu wydają się zbyt oczywiste, aby zasługiwały na naukową uwagę i stąd prawdopodobnie niedostatek tego typu analiz. Nie dotyczy to jednak treści merytorycznych reform (metodyka nauczania, organizacja systemu, projekty programów itd.) czy treści społecznych reform (ideologia), którym poświęcał uwagę choćby sam Szczepański.

Jako że w reformowaniu idee i ideologia wyznawane przez reformatorów znajdują następnie wyraz w przepisach prawnych (Szczepański, 1999, s. 30), warto przyjrzeć się, czy w odniesieniu do nauk prawnych istnieje wiedza dotycząca kompetencji stanowienia prawa. Okazuje się, że ramach tzw. polityki prawa wobec nauki wykorzystywana jest - równolegle z wiedzą naukoznawczą - wiedza z zakresu zarówno inżynierii prawa i strategii kształtowania kultury prawnej, jak i inżynierii polityki i strategii zmiany społecznej, socjologii prawa oraz socjologii nauki (Goćkowski, 2007, s. 116-118). Zgodnie z koncepcją Leona Petrażyckiego polityka prawa ma poprzez swoje wskazówki gwarantować skuteczne prowadzenie społeczeństwa przez prawodawcę do obranego celu oraz usprawniać pracę legislatora i jej efekty. Do skuteczności w tworzeniu prawa przydatna jest inżynieria społeczna dokonywana za pomocą prawa (Pieniążek, Stefaniuk, 2014, s. 252). W interpretacji socjologii prawa racjonalność działań prawodawczych jest niewątpliwie wspierana przez wiedzę społeczną dostarczaną przez prawoznawstwo, teorię i filozofię prawa, teoretyczne nauki społeczne oraz nauki praktyczne, w tym prakseologię. W kontekście tak silnej świadomości naukowych podstaw procesu tworzenia prawa zastanawia tak skromny dorobek nauk społecznych w zakresie naukowych podstaw reformowania. Poniekąd lukę tę wypełniają w ostatnich czasach nauki o polityce publicznej. Według Andrzeja Zybały (2013) istotna jest wiedza o politykach (policy knowledge), która ma dostarczać decydentom użytecznych informacji mających racjonalizować ich działania. Wśród różnego typu analiz 
eksperckich, tuż przed analizą zawartości polityk, autor wyróżnia grupę analiz czynników determinujących politykę - dostarczających wiedzę o tym, jak polityka była projektowana, dlaczego, kiedy i dla kogo. Jednak owe praktyczne zalecenia płynące z teorii nie były w Polsce stosowane. Po 1989 roku pogłębiona wiedza ekspercka o problemach publicznych nie była przez decydentów odpowiednio wysoko ceniona, nie dbali oni również o czerpanie wiedzy z doświadczeń poprzedników w reformowaniu różnych dziedzin życia (Zybała, 2014, s. 66). Można założyć zatem, że i wiedza dotycząca techniki reformowania szkolnictwa wyższego nie była przekazywana kolejnym reformatorom, co niewątpliwie ograniczało uczenie się na błędach poprzedników, zwiększając ryzyko popełnienia podobnych błędów.

\subsection{WIEDZA W REFORMOWANIU}

Modelowanie systemu szkolnictwa wyższego i nauki przed i po 1989 roku stanowi o tyleż ciekawy przykład zaangażowania wiedzy w procesy reformowania, iż manifestujący pewną fluktuację podejścia do wykorzystywania wiedzy eksperckiej. Niezależnie od tego możliwe jest postawienie tezy o większym znaczeniu dla reformatorów wiedzy o reformowanej rzeczywistości niż wiedzy o reformowaniu jako takim. Przede wszystkim chodzi o instytucjonalizację badań nad szkolnictwem wyższym i nauką w Polsce, która w PRL wykazywała silne związki na linii nauka-decydenci, w ciągu następnych dwóch dekad - bardzo słabe, by w trzeciej dekadzie ponownie powiązać decydentów z ekspertami.

Istnieje w Polsce bogata socjologiczna tradycja badania szkolnictwa wyższego i nauki, u podstaw której legła już kilka dekad temu silna świadomość konieczności takich badań naukowych i racjonalnej refleksji w procesach reformowania. W 1976 roku Jan Szczepański w Szkicach o szkolnictwie wyższym (s. 160-161) postulował systematyczne obserwacje i rejestracje przez odpowiednie instytucje badawcze, a także administracyjne i statystyczne działań systemu oraz powołanie organów i urządzeń, które dokonywałyby analiz zjawisk niepożądanych, przekazywanych następnie decydentom wszystkich szczebli. Wskazywał przy tym na dostępne zasoby kadrowe i metodologiczne szkół wyższych, predestynujące je do prowadzenia tego typu działań monitoringowych. Systematyczne badania nad szkolnictwem wyższym były prowadzone w Polsce już na wiele lat przed sformułowaniem tych zaleceń w ramach kierowanej przez ich autora Pracowni Badań nad Szkolnictwem Wyższym przy Uniwersytecie Łódzkim (1960), a następnie Międzyuczelnianego Zakładu Badań nad Szkolnictwem Wyższym w Warszawie (1961-1968), silnie powiązanego z resortem szkolnictwa wyższego. Późniejsze losy tej instytucji, która przekształciła się w Instytut funkcjonujący w latach 70. i 80. pod kilkoma zmo- 
dyfikowanymi nazwami, dowodzą, że istniało w Polsce silne zaplecze eksperckie dla ówczesnej polityki naukowo-technicznej oraz polityki szkolnictwa wyższego (Antonowicz, 2015, s. 47-52).

W pierwszych latach transformacji doszło do osłabienia świadomości potrzeby badań na potrzeby decydentów, co prawdopodobnie jedynie wzmogło bezradność państwa wobec żywiołowych procesów rynkowych w systemie edukacji wyższej, wpływając na „wąłłość i daleko idącą niedoskonałość rozwiązań legislacyjnych” (Ratajczak, 2011, s. 135). Amatorszczyzna w zarządzaniu zmianą w szkolnictwie wyższym i nauce wskazywana przez Jerzego Woźnickiego (2000, s. 56) tym bardziej wymagała przeciwdziałania poprzez odwołanie się do interdyscyplinarnych badań tych sektorów. Podobną opinię na temat niedostatku analiz diagnostycznych wkomponowanych w proces legislacyjny i praktykę prawną formułowała z perspektywy socjologii prawa Anna Turska (2000, s. 25). Badania szkolnictwa wyższego i nauki były prowadzone głównie przez powstałe w 1992 roku Centrum Badań Polityki Naukowej i Szkolnictwa Wyższego przy Uniwersytecie Warszawskim (wydawcę półrocznika „Nauka i Szkolnictwo Wyższe”), ale nie było widoczne bezpośrednie powiązanie tych badań z polityką. Być może dlatego, także w późniejszych w ocenach procesów reformowania szkolnictwa wyższego w Polsce po 1989 roku wskazywany był brak zaplecza systemowego i logistycznego obejmującego wyspecjalizowane zespoły doradców, wpierające decydentów na etapie przygotowania reform (Thieme, 2009, s. 376).

Podejście rządzących do wykorzystywania wiedzy w reformowaniu zmieniło się w zasadzie dopiero przy okazji głośnej nowelizacji Prawa o szkolnictwie wyższym z 2011 roku. Niewątpliwie sprzyjała temu wzrastająca profesjonalizacja polityk publicznych z jej koncepcją polityki opartej na badaniach (research based policy) czy dowodach (evidence based policy). Polityka tego typu ma zapewniać wysokiej jakości informacje pochodzące z różnych źródeł - wiedzy ekspertów, krajowych i międzynarodowych badań, statystyk, opinii interesariuszy, konsultacji i ewaluacji polityk już zrealizowanych. Nie bez znaczenia dla projektowania polityki była też wzrastająca potrzeba generowania wiedzy aplikacyjnej typu mode 2, mającej służyć rozwiązywaniu realnych problemów społecznych (Antonowicz, 2015, s. 34-35). Trendy te były mocno wspierane przez wielkie organizacje międzynarodowe, jak OECD, Bank Światowy itp. Trudno stwierdzić jednoznacznie, aby te zalecane praktyki w pełni przyjęły się w odniesieniu do polityki szkolnictwa wyższego i nauki w Polsce. W pierwszej dekadzie XXI wieku zaczęły się pojawiać różnego typu opracowania eksperckie, które - przynajmniej w deklaracjach decydentów - miały służyć polityce naukowej i polityce szkolnictwa wyższego. O intensyfikacji produkcji eksperckiej w tym czasie świadczą chociażby ogólne 
opracowania zawierające diagnozę społeczno-gospodarczą i wizje przyszłości, jak: Raport o kapitale intelektualnym Polski, Polska 2030. Wyzwania rozwojowe czy raport o charakterze foresightu Polska 2020. Spojrzenie z przyszłości. Najbardziej spektakularnym jednak przykładem aktywności eksperckiej na rzecz działalności decydentów był szereg opracowań analitycznych towarzyszących przygotowywaniu przez Ministerstwo Nauki i Szkolnictwa Wyższego w latach 2009-2010 propozycji strategii rozwoju. Strategia opracowana przez ekspertów z Ernst \& Young i Instytutu Badań nad Gospodarką Rynkową na zlecenie resortu poprzedzona została aż sześcioma opracowaniami szczegółowymi dotyczącymi zarówno diagnozy, uwarunkowań, misji, wizji i celów strategicznych czy analizy trendów międzynarodowych. O ile pozytywnie należy ocenić sam fakt zaangażowania ekspertów w proces projektowania polityki szkolnictwa wyższego i nauki, o tyle efekt tego zaangażowania ocenić trzeba już bardziej krytycznie. Po pierwsze, nie do końca jasne dla opinii publicznej były okoliczności doboru ekspertów (w znaczeniu podmiotów instytucjonalnych), czasu na ekspertyzy, uwarunkowań finansowych. Po drugie, przygotowana w oparciu o bogaty materiał empiryczny propozycja strategii czekała aż pięć lat na zaadaptowanie jej do Programu rozwoju szkolnictwa wyższego i nauki na lata 2015-2030. Brak jest jednak informacji, kto go przygotował, do jakich dokumentów się odwołuje, trudno też ocenić jego jakość diagnostyczną czy poziom uspołecznienia, zalecany przez specjalistów w zakresie planowania strategicznego (Dziemianowicz i in., 2012). Rodzi to pytania o faktyczną użyteczność opłaconych ekspertyz, które po tak długim czasie straciły już nieco na aktualności.

Nowe podejście do reformowania obu sektorów, które reprezentuje nowa ekipa rządząca od jesieni 2015 roku, także dowodzi zwiększonej roli ekspertów w projektowaniu reformy szkolnictwa wyższego. Atrakcyjna skądinąd formuła konkursu na Ustawę 2.0, w którym wyłoniono trzy zespoły eksperckie, niewątpliwie ma na celu pokazanie, że wiedza ma znaczenie w reformowaniu.

\subsection{WIEDZA REFORMATORÓW}

Za reformatorów uznawać można szeroko rozumianych decydentów, w węższym ujęciu chodzi głównie o urzędników ministerialnych (z Ministrem Nauki i Szkolnictwa Wyższego na czele), czyli profesjonalną kadrę administracji publicznej. Wiedza na temat ich wiedzy jest dość skromna, ale doczekała się zainteresowania w związku z procesami profesjonalizacji zarządzania publicznego. W tym ujęciu wiedza reformatorów odnosi się do procesów uczenia się i zarządzania wiedzą w administracji publicznej, w bardziej organizacyjnym kontekście, aczkolwiek 
również w odniesieniu do systemowych procesów reformowania administracji publicznej w Polsce lokowanych w obrębie wzmacniania mechanizmów dobrego rządzenia.

Na uwagę zasługuje cały projekt Ministerstwa Uczące Się (MUS), realizowany w latach 2010-2014 ze środków unijnych, gdyż był przykładem zastosowania naukowo-pragmatycznego podejścia, które zaowocowało poradnikiem dla polskiej administracji rządowej. W dość rozbudowanym od strony metodologicznej badaniu dotyczącym mechanizmów uczenia się polskich ministerstw wyróżniono trzy rodzaje niezbędnej urzędnikom wiedzy: wiedzę o otoczeniu, wiedzę strategiczną i wiedzę operacyjną, którym towarzyszy m.in. adaptacja tej wiedzy (Możdżeń, Olejniczak, Śliwowski, Widła, 2014, s. 16-17). W ten sposób poklasyfikowana wiedza ministerialna (aczkolwiek deklaratywna) wydaje się w pełni odzwierciedlać całokształt wiedzy omawianej w niniejszym artykule, jedynie z przesunięciem czy zazębianiem się pewnych elementów pomiędzy wyróżnionymi kategoriami. Na szczególną uwagę w kontekście wiedzy reformatorów zasługuje wyróżniony przez autorów wymiar operacyjny, który odnosi się do know-how pozwalającego wykonywać pracę w ministerstwie skuteczniej i sprawniej. Badanie dowiodło niestety, że choć urzędnicy wysoko ocenili swoją wiedzę w każdej z trzech kategorii, to nisko wypadła ich ocena w odniesieniu do adaptacji tej wiedzy w każdym z wymiarów. Ponadto słabą stroną ministerstw okazało się niewystarczające oparcie decyzji na twardych dowodach, tłumaczone niską oceną poziomu ekspertyz i analiz zewnętrznych (Możdżeń i in., 2014, s. 69-74, 89-90). Nadużyciem byłoby przypisanie tych samych wniosków resortowi nauki i szkolnictwa wyższego, gdyż badanie nie objęło MNiSW. Można jednak domniemywać, że diagnoza byłaby zbliżona, gdyż pomiędzy analizowanymi ministerstwami nie było w tym zakresie dużych różnic.

Przytoczona ilustracja dotycząca zarządzania wiedzą i uczenia się na poziomie ministerstwa stanowi zbyt mały dowód na poparcie tezy o niskiej wiedzy reformatorów szkolnictwa wyższego i nauki. Można ją jednak traktować w kategoriach przesłanki czy nawet hipotezy, którą warto w przyszłości socjologicznie zweryfikować.

\section{PODSUMOWANIE}

Rola socjologa, zwłaszcza socjologa szkolnictwa wyższego, zobowiązuje do konstruktywnego połączenia wiedzy teoretycznej z praktyczną zarówno w imię aktywności czysto poznawczej, jak i aktywności mającej szanse na praktyczne zastosowanie w świecie polityki publicznej, której wszakże dotyczy owo teo- 
retyczne poznanie. Niedosyt teoretycznego ujęcia procesów reformowania jako działalności praktycznej wymagającej naukowego wsparcia w wymiarze znawstwa i biegłości prowadzi do poszukiwań na gruncie socjologii wiedzy, która od dawna obejmowała już swoją refleksją kwestie sprzężeń na linii wiedza naukowa i praktyka społeczna. Podsumowanie rozważań na temat wiedzy w reformowaniu składa się z trzech pytań i odpowiedzi.

Pytanie pierwsze: co pożytecznego wynika dla polityki szkolnictwa wyższego i nauki z akademickich wywodów na temat roli teoretyka czy eksperta w przemianach społecznych, do których niewątpliwie należą procesy reformowania? Nadrzędnym celem tych rozważań jest uświadomienie decydentom i ludziom nauki złożoności i bogactwa roli uczonego zaangażowanego w działalność na rzecz państwa oraz swego rodzaju nieśmiała próba zachęcenia jednych i drugich do pełniejszego zastosowania wiedzy naukowej wobec reform. Jeden z możliwych wniosków praktycznych jest taki, iż o ile do roli typowego teoretyka-badacza reprezentanci nauk społecznych są żmudnie przygotowywani w trakcie swojej kariery akademickiej, o tyle ekspertami-praktykami raczej bywają z racji pełnionej roli akademików właśnie, nie przechodząc swego rodzaju socjalizacji i profesjonalizacji eksperckiej (poza tą, którą nabywają poprzez przypadkowe doświadczenia eksperckie). Wiąże się to z ryzykiem nieprzystawalności do roli eksperta, w której dany akademik został postawiony, z jej konsekwencjami dla niego samego i dla korzystającego z ekspertyzy decydenta. Dlatego tak istotne jest zasygnalizowanie wagi doboru przez decydentów ekspertów mających zwiększać szanse na obiektywne i rzetelne ekspertyzy.

Pytanie drugie: jakie wnioski niesie rozróżnienie na trzy kategorie wiedzy niezbędne w reformowaniu, postrzegane z perspektywy socjologii wiedzy? Otóż analityczna kategoria, jaką jest metawiedza, pokazuje bardziej wszechstronnie zalety inkorporacji wiedzy do procesów reformowania oraz sprzężenia wszystkich jej odmian, także na zasadzie zależności przyczynowo-skutkowej (wiedza o reformowaniu zasadniczo ułatwia zastosowania wiedzy w reformowaniu i w podnoszeniu wiedzy reformatorów, także w zakresie wykorzystania wiedzy eksperckiej). Najmowanie wyłącznie jednego rodzaju wiedzy, tej sprowadzanej do operowania naukowymi dowodami dla forsowania takiej, a nie innej wizji reformowania, znacznie pomniejsza prawdopodobieństwo powodzenia reformy.

Pytanie trzecie, uogólniające: w jakim celu studiować zagadnienia znawstwa i biegłości reformowania? Najprościej odpowiadając: (1) dla wiedzy teoretycznej związanej np. z próbą konceptualizacji pojęcia kultury reformowania, która pomimo popularności terminów „kultura polityczna” czy „kultura prawna” nie doczekała się jeszcze w Polsce naukowych analiz, (2) dla wiedzy praktycznej, któ- 
ra - poprzez ujęte w ramach konceptu „kultury reformowania” - kwestie znawstwa i biegłości, pomagałaby realizować owe zasady w praktyce życia społecznego.

Oczywiście zawarte w tekście rozważania (oraz zwieńczające je pytania i odpowiedzi) można odnieść do reformy każdego innego systemu społecznego. Niemniej przykład reform szkolnictwa wyższego i nauki jest szczególny z tego powodu, że ów zreformowany z wiedzą i dla wiedzy system generowałby wiedzę dwojako przydatną w reformowaniu innych systemów: jako model działania i jako dobrą praktykę. W ten sposób kierunkiem naprawy szkolnictwa wyższego i nauki w Polsce byłaby przeprowadzona z powodzeniem „reforma oparta na wiedzy”.

\section{Literatura:}

Antonowicz, D. (2015). Między siłą globalnych procesów a lokalną tradycją. Polskie szkolnictwo wyższe w dobie przemian. Toruń: Wydawnictwo Naukowe Uniwersytetu Mikołaja Kopernika.

Boguski, J. (2013). Zarządzanie wiedzą w uczelni wyższej. Nauka i Szkolnictwo Wyższe 2 (42), s. 10-31.

Czyżewski, M. (2012). Wiedza specjalistyczna i praktyka społeczna - przemiany i pułapki. W: A. Jabłoński, J. Szymczyk, M. Zemło (red.), Kontrowersje dyskursywne. Między wiedzą specjalistyczną a praktyką społeczną (s. 71-93). Lublin: Wydawnictwo KUL.

Dziemianowicz, W., Szmigiel-Rawska, K., Nowicka, P., Dąbrowska, A. (2012). Planowanie strategiczne. Poradnik dla pracowników administracji publicznej. Warszawa: Ministerstwo Rozwoju Regionalnego.

Goćkowski, J., Łoś M., Mikułowski-Pomorski J. (1981). Modele socjologii w Polsce. Studia Socjologiczne, 1, s. 49-72.

Goćkowski, J. (1978). „Klerkowie” i „eksperci”. Teksty: teoria literatury, krytyka, interpretacja, 2 (38), s. 63-80.

Goćkowski, J., Machowska K.M. (2005). Status i funkcje eksperta w urządzaniu życia naukowego. Nauka i Szkolnictwo Wyższe, 2 (26), s. 50-70.

Goćkowski, J. (2007). Prawo potrzebne nauce. Nauka 3, s. 113-129.

Goćkowski, J. (2009). Traktat o inżynierii polityki. Studium historycznej socjologii wiedzy o technologii społecznej. Pułtusk: Akademia Humanistyczna im. Aleksandra Gieysztora.

Hausner, J. (2012). Tworzenie i rodzaje wiedzy społecznej. Zarządzanie Publiczne, 1 (19), s. $9-17$.

Leja, K. (2013). Zarządzanie uczelnią. Koncepcje i współczesne wyzwania. Warszawa: Wolters Kluwer Polska SA.

Możdżeń, M., Olejniczak, K., Śliwowski, P., Widła, Ł. (2014). Jak uczą się polskie ministerstwa? Wyniki diagnozy mechanizmu uczenia się. Warszawa: Wydawnictwo Naukowe Scholar. Pobrane z: http://www.euroreg.uw.edu.pl/dane/web_euroreg_publications_files/4737/mus_3_internet.pdf. 
Niżnik, J. (1989). Socjologia wiedzy. Zarys historii i problematyki. Warszawa: Książka i Wiedza.

Pieniążek, A., Stefaniuk, M. (2014). Socjologia prawa. Zarys wykładu. Warszawa: Wolters Kluwer SA, Warszawa.

Ratajczak, M. (2011). Polityka państwa w Polsce wobec szkolnictwa wyższego po 1989 roku i jej implikacje społeczne. Zeszyty Naukowe Uniwersytetu Ekonomicznego w Poznaniu, 173, s. 130-148.

Ravetz, J. (2002). Doradztwo naukowe w gospodarce opartej na wiedzy. Nauka i Szkolnictwo Wyższe, 1 (19), s. 43-50.

Szczepański, J. (1976). Szkice o szkolnictwie wyższym. Warszawa: Wiedza Powszechna.

Szczepański, J. (1995). Ludzie i instytucje. Powstanie Polski Ludowej i przekształcenia społeczeństwa polskiego. W: A. Sułek, J. Styk, I. Machaj (red.), Ludzie i instytucje: stawanie się ładu społecznego: pamiętnik IX Ogólnopolskiego Zjazdu Socjologicznego. Lublin, 27-30 VI 1994. Lublin: Wydawnictwo Uniwersytetu Marii Curie-Skłodowskiej.

Szczepański J. (1999). Reformy, rewolucje, transformacje. Warszawa: Wydawnictwo IFiS PAN.

Thieme, J.K. (2009). Szkolnictwo wyższe. Wyzwania XXI wieku. Polska, Europa, USA, Warszawa: Difin SA.

Turska, A. (2000), Socjologiczna refleksja nad prawem jako czynnikiem organizacji życia zbiorowego. Studia Iuridica XXXVIII, s. 19-32.

Wilkin, J. (2012). Komu potrzebne są nauki społeczne? Nauki społeczne w polskiej i europejskiej przestrzeni badawczej oraz w rozwiązywaniu problemów rozwoju. Nauka, 4, s. 17-32.

Woźnicki, J. (2000). Dylematy modelowe w kształtowaniu systemu szkolnictwa wyższego u progu XXI wieku. Nauka, 4, s. 55-63.

Znaniecki, F. (1984). Społeczne role uczonych, Warszawa: Państwowe Wydawnictwo Naukowe.

Zybała A. (2013). Państwo i społeczeństwo w działaniu. Polityki publiczne wobec potrzeb modernizacji państwa i społeczeństwa. Warszawa: Wydawnictwo Difin.

Zybała, A. (2014). Kultura analizy w polityce publicznej. Jej źródła i teraźniejszość. Studia z Polityki Publicznej, 3 (3), s. 51-70. 